\title{
Local Political Marketing in the Context of the Conservative Party
}

\author{
Dr. Peter Reeves \\ Salford Business School \\ The University of Salford \\ Maxwell Building \\ Salford \\ Greater Manchester, \\ M5 4WT \\ United Kingdom
}

Tel No: +44(0)161 2955720

E-mail: P.Reeves@salford.ac.uk

Paper Submitted to

Journal of Non-Profit \& Public Sector Marketing

"This is an Author's Accepted Manuscript of an article published in Journal of Non-profit and Public Sector Marketing, 2013 [copyright Taylor \& Francis], available online at:

http://www.tandfonline.com/ [10.1080/10495142.2013.760990]." 


\section{Biography}

Dr. Peter Reeves is Lecturer at Salford Business School. He was educated at the University of Birmingham where he earned a Bachelor of Commerce Honours Degree, an MSc in Economic Development Research and Policy and a Doctorate in Commerce. He has held several scholarships most notably the Joseph Chamberlain Scholarship. He has recently been awarded the Vice Chancellor's Early Career Scholarship. His main research interests include political marketing and brand marketing. 
ABSTRACT Local political marketing can be defined as marketing related strategy, activities, and tactics implemented by a political party in a local geographic constituency, in order to attempt to maximise aggregate potential voter satisfaction, and therefore maximise total number of votes and electoral support in the constituency. Through 12 in-depth interviews with Local Constituency Party representatives from the Conservative Party, the study found that local political marketing was acknowledged by a majority of respondents although this was not unequivocal, and was frequently conflated with campaigning. Local political marketing was associated with: visual identity, language/messages, values, image, communication devices, awareness raising, data management and targeting, and simplification. The support from higher levels of the party in local political marketing was varied across constituencies. There was evidence of growing coordination /influence by higher levels of the party in local political marketing. However, this tended to be in seats judged as 'winnable'.

KEY WORDS: politics, marketing, local, conservative, election, qualitative 


\section{Introduction}

The 2010 general election produced a result that can be regarded as truly landmark. After 13 years of the Labour Party in government, and three successive general election victories, New Labour finally 'lost the key to Downing Street' as it no longer could command a majority in the House of Commons. It is beyond the scope of the article to go into detail into the events that followed, but the important issue to note is that the 'traditional' opposition party, the Conservatives, did not have a majority in the House of Commons (despite having won the most parliamentary seats in the Westminster 'first past the post system') and hence could not form a stable government on its own. The outcome of several days of negotiations was that the Conservative Party needed to enter into coalition with the Liberal Democrat Party in order to command a majority in the House of Commons, and form a government. This was the first Westminster coalition in 70 years, and the only Westminster coalition in history between the Conservatives and the Liberal Democrat Party (BBC, 2010). This leads to the question why did the Conservatives fail to a secure a majority? A possible answer to this is in relation to its strategies and tactics in terms of political marketing in target constituencies. Put simply, the party did not win enough of its target seats to secure a majority, and therefore it follows that one factor which contributed to this situation must be how local political marketing was conducted in constituencies.

For the international reader who may not be familiar with the U.K political context, it may be useful to briefly review the main features of the U.K political environment. Elections to the Westminster House of Commons Parliament take place through the U.K general election. Members of Parliament (MPs) are elected from 650 geographic constituencies, whereby voters elect their MP on a 'First-Past -The -Post' system of voting. There are three major political parties in the U.K which are; the Conservative Party (which won 307 constituencies in 2010), the Labour Party (which won 258 constituencies in 2010) and the Liberal 
Democrats (which won 57 constituencies in 2010). Elections are called up to a maximum of every five years. Political parties will typically elect via their internal party membership a Prospective Parliamentary Candidate (PPC; hereafter referred to as a 'candidate') to contest an election in a particular constituency. Hence, the candidate who then goes on to secure the most votes from constituents in their geographic constituency will then be elected to serve as their MP in the House of Commons. An important feature to recognise is that different constituencies have greater likelihood than others (because of political-historic reasons) of being won by a particular political party. For example, some constituencies are regarded as 'safe seats'. This means that that in a Conservative 'safe seat' a rival political party is very unlikely to win the seat from the Conservatives, no matter how much political marketing activity occurs. Conversely where a rival political party holds a 'safe seat' then it is very unlikely that the Conservative Party (no matter the level of constituency political marketing investment) will win the seat. A third category of seats is a 'marginal seat' whereby two or more political parties stand a reasonable chance of winning the constituency. It is in these marginal constituencies where competition is most intense. In the context of the Conservative Party, a ranking of constituencies will be completed by Conservative Central Office, according to their perceived prospects of victory. Decisions are then made on campaign strategy to maximise electoral success. However, this strategy for 'marginal target seats' is kept out of the public domain. It is the Local Constituency Parties or as termed in the Conservative Party, Conservative Associations (hereafter referred to as local parties), who have the responsibility to fight an election campaign in a constituency. However in most cases there is significant input by the candidate. In some cases influence and support from the central and regional Conservative Party is present, dependent on the relative importance or otherwise of a particular constituency in securing a Conservative majority in the Westminster Parliament. 
Before this paper progresses any further it may be useful for the reader to be offered a working definition of local political marketing. Hence local political marketing may be defined as 'marketing related strategy, activities and tactics implemented by a political party in a local geographic constituency in order to attempt to maximise aggregate potential voter satisfaction, and therefore maximise total number of votes and electoral support in the constituency'.

\section{Previous Literature and Theoretical Context}

There is a substantial literature in political marketing that has grown considerably over the last 30 years, and as such is becoming increasingly international in scope (e.g Bowler \& Farrell, 1992a; Cosgrove, 2007; Lees-Marshment, 2001a; 2004a; Lilleker and LeesMarshment, 2005; Maarek, 1995; Newman, 1999; Newman \& Sheth, 1985; 1987; O’Shaughnessy, 1990; O’Shaughnessy \& Henneberg, 2002). According to Lees-Marshment (2001a) a political party can be classified as following one of three political marketing orientations. The first is a 'product orientation; and is where a political party 'argues for what it stands for and believes in. It assumes that voters will realise that its ideas are the right ones, and therefore vote for [them]. This type of party refuses to change its ideas... even if it fails to gain electoral... support' (Lees-Marshment, 2001a: 28). The second classification is a 'sales orientation' whereby a political party 'focuses on selling its argument to voters. It retains its pre-determined product design, but recognises that the supporters its desires may not automatically want it. Using marketing intelligence... the party employs the latest advertising and communication techniques to persuade voters' (Lees-Marshment, 2001a: 29). The third and final political marketing classification is the 'market-oriented' party where a party 'designs its behaviour to provide voter satisfaction. It uses market intelligence to identify voter demands, then designs its product to suit them ... It will not simply offer what they want, or simply follow opinion polls because it needs to ensure it can deliver the product on 
offer' (Lees-Marshment, 2001a: 30). Lees-Marshment's (2001a) model has been evaluated in a comparative context (Lilleker \& Lees-Marshment, 2005), and the orientation followed obviously depends on a number of factors including an individual political party's context, the country where it competes, and the relative level of democratisation within an electoral situation. Reeves et al (2006) considers Lees-Marshment's (2001a) framework and argue that major political parties in Britain are tending to move away from the more ideological driven approaches embedded in the 'product' or 'sales orientation', to a greater tendency to follow a 'voter driven strategy', which is more akin to Lees-Marshment's (2001a) 'market orientation'. This philosophical discussion leads to a justification underpinning this paper, as if political parties are making increasing use of a 'voter driven strategy', then it is worthwhile to consider how political marketing is being conducted by a political party at the lower level scale of constituencies; an area which is under-represented in extant research.

There is a developing literature on local political marketing in international contexts. Towner and Dulio (2012) discussed how political campaigns could micro-target via email, as well as use 'get out the vote' strategies amongst their supporters via personal email or text messages. They convey how personal e-communication tools such as text messages and email can be tailored to meet the perceived needs and concerns of voters. Furthermore they explain how:

'smartphone applications allow for volunteers who are canvassing a neighbourhood or district to use a GPS to easily find a targeted potential voter, deliver an in-person message to the individual, record their attitudes on issues for a separate communication later, and record their willingness to volunteer or donate.' (Towner \& Dulio, 2012: 104).

Likewise Panagopoulos and Francia (2009) stressed the importance of the ground campaign and grassroots mobilization in the U.S 2008 Presidential race. They suggested that: 
'microtargeting has moved into the realm of electoral politics and has become a common technique for parties and candidates to mobilize voters. Microtargeting identifies whether someone is likely to support the party's candidate based upon sophisticated data modelling techniques that are generated from an extensive database of demographic, socioeconomic and consumer information of individual voters, which campaigns collect from various sources... In short, microtargeting helps identify not only whom to target but what to say to specific voters' (Panagopoulos and Francia, 2009: 322).

However what Towner and Dulio (2012) are keen to stress is that the use of personalised digital marketing is not as significant in expenditure terms, than television advertising. Kaid (2012) stresses that many local and regional campaigns cannot afford the high cost of television advertising, but drawing upon Panagopoulos and Green (2008) she argues that radio advertisements can be beneficial to local candidates. Johnson's (2012) commentary on U.S political consulting is also illuminating, as it shows that in the U.S during 2006-7 there were some 47 professional campaign firms providing grassroots organizing services, 126 direct mail firms, 14 targeting consultancies and some 34 consultancy firms providing computer services and political software.

Hutcheson (2006) provides an insightful commentary on the political consulting industry in Russia in which he argues that political consultants are increasingly working with individual candidates in constituencies. He furthermore suggests that the consultants in Russia recognise the value of pre-election constituency research. In Australia, Ward (2003) discusses how the Liberal and Labor Party were increasingly being influenced by local campaigning strategies especially in marginal target constituencies, and were using computerised databases and direct mail systems. Hughes and Dann (2010) argue that:

'Most political marketing campaigns in Australia now run localized versions of the national and state campaigns. Local issues are identified, with the aim of identifying what local issue is of greatest importance to each target seat... The party's stance on these issues is then highlighted in localized promotional campaigns to make the segment aware of how the party is addressing these issues' (Hughes \& Dann, 2010: $85)$. 
Lees-Marshment (2009) discusses how in key seats during the 2008 New Zealand election, segmentation and targeting was used to inform direct mail, although she acknowledges it was not used to its full potential. This is perhaps partially explained by Zvulun (2012) who found in New Zealand a preference for the electorate to receive information about elections from newspapers.

More specifically, the political science literature criticises the Conservative Party in Britain in terms of the effectiveness of their local campaigning strategy (Denver et al, 2004; Fisher \& Denver, 2008; Whiteley \& Seyd, 2003a; 2003b). For instance Fisher and Denver (2009) conducted a comparative analysis of constituency campaigning in the general elections between 1992 and 2005 and found that the Conservative Party had been less effective at local campaigning than its electoral rivals. In addition, Whiteley and Seyd's (2003a) empirical analysis of the 1997 general election shows that the local campaigning effectiveness was weaker for the Conservatives than that of Labour and the Liberal Democrats. A possible reason for this poor performance is that Conservative local parties have a reputation for being independent and are therefore resistant to what they perceive as central party interference (Fisher \& Denver, 2008; Whiteley \& Seyd, 2003b).

\section{The study's rationale}

There is a tendency in political marketing research to look for explanations by examining the strategic context. This study however proposes a different approach by analysing local political marketing at the grass roots of the Conservative Party, in order to understand and build theory in relation to local political marketing. This study offers a timely contribution to the literature as there are clearly lessons that need to be learnt in relation to local political marketing. The study makes a contribution to knowledge given: (1) the lack of literature in local political marketing in both the Conservative Party, and in relation to other political 
parties, and (2) the limited prior use of qualitative data collected at the grassroots of political parties in order to explain and understand more fully local political marketing. More specifically the motivation behind the study is to contribute to knowledge in relation to three research domains, which can be addressed by the following questions: Does a political party acknowledge the use of local political marketing? If so, what does local political marketing mean both conceptually and practically? How can a political party support and facilitate local political marketing? These questions are important to address so that an understanding of how local political marketing functions can be gained, so as to build theory which may be replicable to other political parties. It aims to provide a theoretical and methodological approach for future research into local political marketing.

\section{Objectives of the Study}

Much of the existing literature on political marketing in the Conservative Party focuses predominately on national or strategic issues. These include: (i) general election analyses and commentaries (Lees-Marshment, 2001b; 2005a; Seawright, 2005); (ii) conceptual viewpoints (Lees-Marshment, 2001b; 2004b; Lees-Marshment \& Quayle, 2001); (iii) analysis of political advertising strategies (Dermody \& Hanmner-Lloyd, 2005; Dermody \& Scullion, 2001); (iv) an analysis of Cameron's successful leadership election (Ormrod, 2007 et al ); (v) a content analysis of press coverage (Harris et al, 2006), and; (vi) historical reviews of political marketing up to and including the leadership of Thatcher (Scammell, 1994; 1995; 1996; Wring, 1996).

Despite such literature, it remains to be firmly established whether or not the Conservative Party perceives itself to be undertaking local political marketing. A criticism which may be levied at the existing political marketing literature is that sometimes there is a taken for granted assumption that political marketing activities are utilised without actually empirically 
establishing this to be the case. This study therefore posits the following foundational research objective $(\mathrm{RO})$.

RO 1: To ascertain whether and to what extent there is acknowledgement of local political marketing in the context of the Conservative Party.

It can be argued that local political marketing research lacks specificity in relation to what the local political marketing construct means. There are however a number of contributions which hint at possible characteristics of local political marketing. For example, Lilleker (2006) highlights the importance of local political messages and the 'ability to get the message across effectively within the campaign period' (Lilleker, 2006: 214). Lock and Harris (1996) alludes to the party as a brand name, which can be attached to 'differing products' (Lock \& Harris, 1996:17) such as; candidates, local parties and Conservative social organisations. Jackson (2005a) suggests that party web sites are used to mobilise volunteers at the local level so that a political marketing strategy can be delivered during an election, and Lilleker (2005a) highlights the importance of local leaflet delivery. Baines et al (2003) found that local political marketing issues appear heavily in their five technical service features (local policies, [local] candidates, national policies, leaders and values).

A regular theme which emerges from the local political marketing literature is the role of local party politicians and members in the implementation of local political marketing strategies. For example, Butler and Collins (2001) and Lilleker (2005a; 2006) highlight the value of permanent campaign that focuses on politicians providing a constituency service as an element of their constituency political marketing strategy. Lilleker (2005a) stresses the importance of members in canvassing and the 'knock up' of supporters on election day and exclaims that they 'are the party's foot soldiers, they will run local offices, organise and coordinate campaigning activities... they are the lifeblood of a party' (Lilleker, 2005a: 572). 
The importance of data and targeting also underpins the local political marketing literature . A comprehensive local political marketing planning process is presented in Baines et al (2002), comprising market research, constituency ranking, competitor analysis, electoral segmentation and targeting, positioning and post- election analysis. Lilleker (2006) highlights the use of technology to reach and identity floating voters. Savigny (2005) notes the 'targeting of floating voters in strategic seats', by 'broad image management at national level, and a highly individualised segmented and personalised campaign at local level' (Savigny, 2005: 926).

Possible components of the local political marketing may include messages, local policies, data and targeting, the brand name of the party, and communication tools (such as leaflets and web sites). However, what the local political marketing construct actually means from the perspective of Conservative local parties has not been well addressed in the extant literature. Hence the following research objective is posited:

\section{R02: To understand what local political marketing means conceptually and practically in}

\section{the context of the Conservative Party.}

A theme which emerges from the existing literature is the relationship between the central and local parties in terms of local political marketing (Butler \& Collins, 1994; Egan, 1999; Harrop, 1990; Lilleker, 2005b). Egan (1999) argues that most political marketing models neglect the value and importance of the local campaign because political marketing is viewed as a centralised strategy determined by the national party. Butler and Collins (1994) suggest that given the use of permanent marketing professionals in political parties, volunteers tend to follow their instructions and undertake operational tasks. Lilleker (2005a) questions the value of nationally and centrally orchestrated political marketing and argues for a more localised and focussed communication strategy. 
There is also some historical commentary whereby one may discern political marketing ICT support given by higher levels of the Conservative Party to lower levels of the organisation. For example, it can be observed in Farrell and Wortmann (1987) and Yorke and Meehan (1986) how very early steps in the run up to the 1983 general election were being taken to use computer technology in important local constituencies for the purposes of personalised direct mail to key voters. More recently, Seawright (2005) discussed political marketing during Michael Howard's leadership of the Conservative Party and informs readers of 'Voter Vault', which was used by the Conservative Party in the 2005 general election. This information technology system included Mosaic data provided by Experian. It is likely that the Conservative Party would have updated its support systems for local political marketing in ways not reflected in the existing literature. Hence the following research objective is proposed:

RO3: To understand what support is given by the Conservative Party in order to facilitate local political marketing

\section{Method}

This exploratory study comprised 12 depth qualitative semi-structured interviews. The respondents were sampled according to the principles of 'theoretical sampling' (Glaser \& Strauss, 1967; Strauss \& Corbin, 1990) whereby respondents were selected on the basis of emerging theoretical directions of the research. The theoretical requirements of the sampling were:

(i) for interviewees to be the lead individual responsible for political marketing in a Conservative local party. It was important that the study interviewed the 'lead' 
person responsible for political marketing in a local party so as to generate the most valuable data.

(ii) for data to be collected in local parties where there was not a sitting Conservative MP before the general election of 2010, or an incumbent MP was not contesting the election, and hence there was a new candidate. This approach was taken as the study sought to focus on political marketing activities where fresh approaches towards political marketing are more likely to be utilised, as a result of a new and unestablished candidate contesting the seat.

The Conservative Party website in the run up to the 2010 election included listings of constituencies and links to e-mail and/ or local party web sites. The research therefore identified potential respondents through this means and e-mailed to request interviews. Data was collected from a variety of constituencies with differing likelihoods of electoral success in the 2010 election, and were widely geographically spread throughout England. Interviews were undertaken face-to-face between November 2009 and June 2010. The interviews lasted for an average of around 47 minutes each, and were audio-recorded and transcribed verbatim. This resulted in around 89,000 words of interview data. The interviews were transcribed by an audio-typist. Drawing upon the interpretivist tradition, the data was systematically coded and organised according to each of the study's research objectives with an aim of finding patterns in the data (Miles \& Huberman, 1984).

\section{Theory Building}

The specific approach to theory building in this study is conditioned by Strauss and Corbin (1990) and Glaser and Strauss $(1967 ; 1999: 1)$ who argue that theory should be discovered and grounded in empirical data, so as to "provide relevant predictions, explanations, interpretation and applications... through a general method of comparative analysis'. The 
theory that is built is therefore grounded in the data and can 'offer insight', and 'enhance understanding' through the development of 'a set of well developed concepts... that can be used to explain or predict phenomena' thereby enabling concepts to be formulated into a 'logical, systematic and explanatory scheme' (Strauss \& Corbin, 1990: 12,15,21). In this study, constant comparison is used to build substantive theory by analysing data, and developing codes and categories which allow exploration of similarities and differences between data sources up and until the point of 'theoretical saturation' (Glaser \& Strauss, 1967; 1999; Strauss \& Corbin, 1990). Hence, it is a 'middle range'(Bourgeois, 1979; Glaser \& Strauss, 1967; 1999; Merton, 1968; Strauss \& Corbin, 1990) theorisation approach. Theory is built that 'fits' and 'works' according to the context of the study, yet at the same time may have theoretical generalisability to other contexts (Glaser \& Strauss, 1967; 1999; Strauss \& Corbin, 1990).

\section{Reliability and Validity}

Given the interpretivist orientation of this study, Lincoln and Guba's (1985) 'trustworthiness' concept (i.e. credibility, transferability, dependability, confirmability) provides the framework for assessing the reliability and validity of the research. The credibility and internal validity of the data was enhanced by triangulation and peer debriefing (Lincoln \& Guba, 1985; Riege, 2003). Triangulation was achieved by interviewing across multiple local parties, thereby enabling what Denzin (1978, cited in Creswell \& Miller, 2000; Lincoln \& Guba, 1985) identifies as data source triangulation (i.e. participant triangulation via the dual domains of spaces and persons (Denzin, 1970)) . Peer debriefing (Morse et al, 2002) was also used in the study whereby the paper was presented to a symposium of political marketing experts who asked questions about the research approach and made suggestions for improvements to the manuscript. In addition, all interviewees were assured that their responses would be fully anonymised in the write up of the study. 
In order to verify the findings, a systematic audit trail was also established throughout the data (Bowen, 2009; Gabriel, 1990; Morse et al, 2002). This was achieved by assigning interviewees with a unique identification code which could be used to track how the explanation had been developed from the data. A second coder comprehensively checked the entirety of the coding process (Creswell, 2007), that was followed for the production of this article. On occasions where disagreement was found between the interpretation of the lead researcher and the second coder, this was discussed and necessary amendments were made to the study. These processes increased the dependability and confirmability of the data (Lincoln \& Guba, 1985; Riege, 2003).

The transferability of the data to other contexts is also enriched by thick description via narrative and verbatim quotations that allow the reader to 'reach a conclusion about whether transfer can be contemplated' (Lincoln \& Guba, 1985: 316).

\section{Findings and Discussion}

The paper will now discuss the findings that emanate from this study. The approach taken is to discuss the research findings in relation to relevant political marketing literature.

\section{Acknowledgement of Local Political Marketing in the Conservative Party}

The study found that there was an acknowledgement from a majority of respondents that local political marketing was utilised in their constituency. It should however be stressed that in some cases this view was not unequivocal, as some respondents seem to imply some degree of reservation about the extent and prevalence of political marketing. This researcher would posit that some of this reservation seemed to stem from linguistic conflation of the 
political marketing idea with more readily used language of campaigning. Furthermore it was apparent that where interviews were undertaken with candidates, they tended to question whether local parties were effective at political marketing, as they perceived them to have a lack of understanding in this area. Hence political marketing in these instances seemed to be perceived by candidates as their 'preserve', rather than a job for a local party.

\section{Political Marketing and Conflation with Campaigning}

It was noticeable from the data that political marketing was frequently conflated with campaigning. Although there may be synergies between campaigning and marketing (Baines et al, 2002), it would be inappropriate to simply 'bolt on' (Baines \& Egan, 2001) campaign strategy to political marketing, without necessary adaptation (Reeves, 2007). However, one respondent showed a more nuanced interpretation of the relationship between campaigning and political marketing as demonstrated by the following extract:

'Respondent: A political campaign is an element of marketing, it's not the sole element of marketing. I mean marketing is a broader definition, I would say, than a campaign. Although a campaign is probably going to be $80 \%$ of any political marketing.

Interviewer: So what's the difference then, what the difference between campaigning and political marketing?

Respondent: Campaigning is a tactic; a big it's a sort of umbrella term, for a series of tactics that would form part of an overall marketing mix....' (Respondent 1)

\section{The Relationship Between Political Marketing and Commercial Marketing}

A notable feature of the data was that the majority of respondents did seem to have some degree of marketing and/or business background. One respondent claimed that the Conservative Party is seeking to learn from business about marketing. In keeping with the political marketing literature which suggests that there are differences between the 
commercial and political marketing (Baines \& Egan, 2001; Butler \& Collins, 1994; Egan, 1999; Lock \& Harris, 1996; O’Shaughnessy, 1990) another respondent described how he expected political marketing to utilise business style marketing. However he found that the way things were done in political parties were different, and that political marketing has 'quite a rigid template' (Respondent 2) as to how things should be done to win an election. It was argued by another respondent that he has learnt that business models cannot be superimposed onto political parties. As the respondent stated:

'when I got involved in politics one of the things I was looking at was how do you superimpose a business type of framework or ideals onto a political party unit? ... political parties are very very different animals. There are obviously structures but they are also a volunteer party. It is not a corporate entity... What I was trying to do was say well how does this work, how does the party work, is it a corporate entity that I can recognise and actually it isn't. It's a confederation of ideas and values and beliefs'. (Respondent 3)

\section{What is Local Political Marketing?}

The study explored with respondents what political marketing means at a local level. An eclectic range of interpretations of local political marketing emerged from the data which will now be discussed.

\section{Visual Identity}

Political marketing literature frequently alludes to the importance of logos (e.g. Bowler \& Farrell, 1992b; Lock \& Harris, 1996) and visual identity (Reeves, 2007; Wring, 2002). The visual identity and logo of the Conservative Party was a frequently recurring theme in the study. The redesign of the Conservative Logo from the 'torch of freedom' to the 'oak tree' still remains a topical issue in the party. Respondents reported recent historical tensions in the party over the new logo. It now appears that the new logo has become more accepted in the party, and the task in the general election was to build and further electoral recognition of the logo. As a respondent stated: 
'We have a relatively new $\log$..., which is our tree. We've been trying to get that ... message out and trying to get that brand recognised' (Respondent 4)

It should however be stressed that universal acceptance of the new logo is still not achieved,

which is demonstrated well in the following data.

'I mean there was a lot of discussion and anger about the Oak Tree at the time, people saying that they really hated it and bring back the Torch. I think that the Oak Tree will be down played at the actual election' (Respondent 5)

'It really restricts your marketing because it is a logo that does not work in black and white. Black and white is a disaster.... the Torch worked also in black and white' (Respondent 5)

\section{Languages and Messages}

There is a substantial body of political marketing research which emphasizes the importance of language, slogans and messages for political parties (e.g. Baines et al, 2002; Harrop, 1990; Niffenegger,1989; Reeves, 2007; Reid, 1988). Accordingly, the importance of language and messages became a frequent theme to emerge from the data in this study. As seen in the following interview excerpts, the need for message consistency, clarity and repetition were advanced.

'I think it's important to be consistent in your messages... otherwise people don't know what you stand for' (Respondent 6)

'I have about 3 messages that I hammer home over and over again' (Respondent 7)

There was also evidence to suggest a desire for the party to avoid messages which might be electorally perceived as being right wing. As a respondent stated:

'no, no, no, no, we're not making this strong message on immigration and it wasn't until right at the end of, hmm, the campaign that they changed their direction. ... Now I understand where it came from because in previous elections we'd been seen as far too right-wing' (Respondent 8). 
The literature widely recognises the role of values in political marketing (e.g. Baines et al, 2003; Butler \& Collins, 1994; Henneberg, 2002; Newman \& Sheth, 1987; Reeves, 2007). In keeping with this research a substantial majority of respondents provided evidence to suggest that political marketing was associated with the party's values. It was articulated that there needed to be alignment of Conservative Party values with the values of the party membership, candidates and electorate. There however did seem to be some degree of recognition that there may be competition between party values and the electorate's needs (Reeves, de Chernatony \& Carrigan, 2006).

However, when the study asked respondents what they believed Conservative values to be, the results showed a distinct lack of consistency in expressing what the values actually were. Instead, respondents came up with over twenty five different values with very limited duplication between respondents. For example, the most frequent were in each case only cited by two respondents and were freedom, responsibility, entrepreneurship, and smaller state. In addition, one respondent in each case provided evidence to suggest that Conservative values included a diverse range including, for example, respect, tolerance, social justice, equality, deregulation, environment, localism, individualism, aspiration. Hence it is of some concern that respondents could not clearly express in a consistent manner what Conservative values are. If respondents cannot express in a simple and coherent manner what their values are then they may struggle to communicate to the electorate in a condensed and understandable manner what the Conservative party stands for, and why they should feel inclined to vote for it. 
Image

The conceptualisation of image, was in terms of image of the party and image of the leader (e.g. Baines et al,2005; Newman, 1999; Nimmo, 1975; Schneider, 2004; Shama, 1975;

Smith, 2001). One respondent cogently stated with reference to the image of the leader: 'the leader embodies the Party's image' (Respondent 4). This echoes the argument made by Needham (2006) that a political party's leader acts as: 'a shortcut to sum up all the desirable attributes of the party' (Needham, 2006: 182)

In terms of the image of the party, it was argued that because the party has lost three elections, there has been need to reposition the party. It can therefore be deduced that the Conservative Party under the leadership of David Cameron has attempted to adopt a greater 'catch all' (Kirchheimer, 1966) orientation. This has been achieved by re-positioning on the 'centre ground' so that it is more likely to appeal to the widest possible cross section of electoral opinion (Reeves, 2007; Smith \& Saunders, 1990). As a respondent stated:

'It's also about positioning the party. And what Cameron has done, his strategic positioning has been to reach out to the centre ground. To not keep nodding to the right to shore up the core vote, but to reach to the centre.' (Respondent 1)

The changing image of the party can also be seen clearly in the following interview excerpt:

'I think what David Cameron's done over the last five years since becoming leader, he's tried to change people's perception of the Conservative Party and our brand and we've tried to become slightly more open, slightly more diverse party that recognises people. .... So I think we've been trying to convey that message that we've changed.., the party's changed' (Respondent 4)

\section{Communication Devices}

A wide array of communication devices were used by the Conservatives in local political marketing including: direct print media (e.g. newsletters, leaflets, letters, direct mail, tabloids, election addresses); indirect print media (e.g. local press coverage, letters to press); local 
broadcast media (e.g. radio) and; internet technologies (e-mail, newsletters, blogs, websites social media outlets etc). It should however be noted that there is still a reliance on 'traditional' communication devices rather than e-communication tools, as the primary means of electoral communications. One respondent who had one of the most developed political marketing strategies described her use of internet for political marketing practices as being 'embryonic' (Respondent 1). The reasons for the lack of enthusiastic adoption of etechnologies included difficulties in collecting e-mail addresses of local constituents for targeting purposes, and a genuine nervousness in the use of social media techniques for fear of making a fatal web posting that irrevocably damages their candidacy and/or wider electoral prospects for the Conservative Party. Thus local parties seem in some cases to be internet averse.

\section{Awareness Raising}

A central objective of local political marketing was perceived to be in terms of raising awareness of the party in general terms, and /or of the candidate. The need to raise awareness may be required partially to redress electoral apathy in a constituency. Hence a significant challenge rests upon a candidate and his/her team to at least be recognised by his/her potential constituents. It then follows that if a voter can recognise the name and/ or picture of a candidate in the local press, or see him/her around the constituency, this is likely to reinforce a positive image of the candidate who is more likely to be perceived as 'working for the needs of constituents'. Alternatively if the electorate are unaware of the candidate, then they are likely to miss such positive cues. Hence the need to raise awareness, at least at a superficial level, is essential given that a candidate is never going to be able to spend significant time with a large number of his constituents, and in many cases may never meet some of them. 


\section{Data Management and Targeting}

A frequently recurring theme of the interviews was surrounding the use of canvassing techniques. It was noticeable that some of the respondents were making a concerted effort at using data to target voter segments. The principal means through which this was achieved was through the use of a Conservative Party information system. This technology is known simply as Merlin. The system had essentially two functions regarding issues of data management. The first function is a platform through which local parties could add locally collected data. This took principally the form of the number of pledges (i.e. promises to vote Conservative) that a particular candidate had received from potential constituents. One respondent stated that he worked on the principal that $70 \%$ of pledges would result in a vote for the candidate in the constituency (a figure very similar to Seawright's (2005) article which argued that a precursor to Merlin; that being Voter Vault could successfully predict $69 \%$ of pledges). Evidence was presented to suggest that this pledge base may be accessed and monitored by the centre to assess progress of the local parties. It was however noticeable that collection of voter intention was the principal concern of Merlin users. In addition, some local parties collected data on voter concerns which could be collated in Merlin. However this process of data collection did not seem as common across local parties as one might expect. Where data was collected, it seemed to be in better resourced local parties who stood a better chance of electoral victory. Techniques of data collection included traditional doorstep canvassing, pre-paid return postal questionnaires, and telephone canvassing.

The local parties that used Merlin seemed to be increasingly reliant on the second function of the system; that being the use of commercial consumer intelligence and national co-ordinated polling evidence which was used to undertake targeting. The Conservative Party was making increasing use of Mosaic segmentation and targeting techniques. Thus the Conservative Party has in some circumstances utilised analyses based on geo-demographic and lifestyle 
segmentation techniques. Hence there was evidence of political segmentation (Baines et al, 2003; Murray \& Scime, 2010; Phillips et al, 2010; Smith \& Hirst, 2001; Yorke \& Meehan, 1986) and 'customisation' of political messages to appeal to different voter segments (Henneberg \& Eghbalian, 2002).

Examples of the use of the Merlin system are clearly demonstrated in the following quotations:

'we have used Mosaic as a form of endeavouring to select particular styles of individuals... And we are targeting them with direct mail, .... and then it would be particular subjects that would be directed to the likely inhabitant of that particular type of property or area or something. So that's what we have tended to do but that is all the information from a remote source, if you like as opposed to what we are trying to do ourselves' (Respondent 2)

'Respondent: But we also use commercial databases, segmentation databases.

Interviewer: Yes ok. Tell me a bit about these commercial and segmentation databases?

Respondent: Well, they have categories of different types of geo-demographic lifestyle data, and we analyse those that we think are most likely to vote Conservative, or are most likely to switch to vote Conservative. We use them to target based on research...

Respondent: We communicate with them through a range of different ways. So we'll target leaflets, or direct mail, or emails, or particular campaigns depending upon the issues and interests that particular segments or voter groups have' (Respondent 7)

However, it should be stressed that according to at least one respondent the data was used to inform communication, rather than fully determine electoral messages. As she states:

'I do think it's important that certainly as a candidate I don't just define my messages by second-guessing what constituents want to hear. I think that's a slippery path ...it informs me, but it doesn't necessarily define my every message' (Respondent 1)

Another respondent who used comprehensive data collection and analysis techniques commented on the operational difficulties of using targeted communication.

'if we're doing a piece of direct mail to 5 different segmentation groups, then we have to do 5 different letters, organise them all into walks, organise them into the right 
order and the right house and the right street for the deliverer to deliver. That is hugely time-consuming. ... If that was a commercial organisation, we'd outsource it to the mailing house... obviously we can't do that, because we don't have the money to do that.' (Respondent 7)

The use of the aforementioned sophisticated data targeting systems was not however as prevalent throughout the Conservative Party as it perhaps may be expected. The study found that more weakly resourced local parties were not engaging in such data collection and analysis techniques. The Merlin system was not used by around half of the local parties researched, and hence in these cases there did not seem to be any real concerted attempt to collect data. The primary reason for this appeared to be concerns about whether a local party would have sufficient resources to use such a system.

\section{Simplification}

Over half of respondents presented evidence to suggest that local political marketing is associated with simplification. This is consistent with political marketing literature which asserts the need for simplification (e.g Needham, 2005; 2006; O'Shaughnessy, 2001; Reid, 1988; Schneider, 2004) This included the need for simplification of messages in order to enable effective communication to the electorate. As a respondent argued, we have got to try and package messages:

'in such a way that, that the electorate, most of whom are not that interested in politics, day-to-day, will find easy to digest and easy to understand and will help them make an informed choice' (Respondent 4)

\section{Support Provided by Higher Levels of the Party on Local Political Marketing}

The study also asked respondents to comment on the level of support given by higher levels of the party in order to facilitate local political marketing. The responses gained were highly 
varied with comments evidencing limited support, to improving levels of support, or good levels of support. Support given did not seem to be defined clearly in terms of the language of political marketing. Rather it tended to be defined in the semantics of campaigning. This was especially the case for training, as the following excerpts aptly demonstrate:

'Interviewer: Is there any training on political marketing available?

Respondent: Yes.

Interviewer: And is it called political marketing?

Respondent: No it's called campaigning.

Interviewer: This is a theme I pick up. They call campaigning political marketing. Why do you think they do that for?

Respondent: Because that's what it is' (Respondent 3)

In addition, respondents reported that there were no documents or briefing notes from higher levels of the party on political marketing. Where support was given to local parties it seemed to emanate from regional offices, via a network of party professionals, who were focussed around clusters of target seats.

The most visible level of support was in terms of provision of visual brand identity guidance and notably the provision of templates. As one respondent stated:

'You will get sent materials to look at. Received a huge A4 ring binder before Christmas which had the full range of, I guess what you would call products, marketing products that you can buy, you can use during the campaign, leaflets, posters, stickers, cards, Christmas cards, birthday cards, template letters. I mean a full range' (Respondent 4)

Such templates were means of disseminating national content, but with scope for the addition of local content.

Information technology systems were also used to provide support to local parties with frequent e-mails from the centre (although in the language of campaigning or the "party line'). In addition, whilst Conservative internet systems did provide clear benefits for local 
parties, some respondents seemed concerned about the clarity of technology systems, and there seemed to be 2-3 internet web site systems for local parties to use, rather than one fully integrated and comprehensive system. Moreover, there was some degree of difficulty in using the systems provided. For example, one respondent stated:

'Well I think in the first few weeks it was difficult to get my head round it, I must admit it and I kept trying it. But I thought it was operator error rather than the fact that the system didn't work. But once I got used to it, hmm, I found it a very useful tool' (Respondent 8)

The study found some evidence of the growing co-ordination and influence of higher levels of the party in local political marketing. The following quotes exemplify the co-ordination of local political marketing activities.

Respondent: 'Whereas previously the scenario has been the candidates have possibly been loose cannons allowed to get on and do whatever they felt they want to do in their own patch... it's much much more co-ordinated this time round.

Interviewer: Right. In what ways is it co-ordinated?

Respondent: Its co-ordinated... every single letter or press release that I may issue has to be vetted by in this instance the Regional Press Officer ' (Respondent 2)

'Interviewer: what are they checking for?

Respondent: 'Are you saying anything stupid?'... “Are you making spending pledges?" They always want candidates to be very careful not to make a spending pledge that is unsubstantiated by national party policy. Also it is to check that we are expressing things in the right tone, the right content as it were. It's just to make sure that we are all on message, but it's tonal as much as content.' (Respondent 9)

Other evidence of central co-ordination could be seen in terms of local campaign meeting team agendas being set by central office, a clear division between the regional professional party and regional voluntary party, and use of reports and campaign plans in order to assess progress in key constituencies. Thus there does appear to be evidence in some constituencies of Panebianco's (1988) ‘electoral professional' model of party governance gaining influence whereby 'careerists' in the professional party assume ever greater influence over political 
marketing strategies. This is consistent with existing research which has shown a tendency when political parties introduce marketing strategies, to move to a more 'top down', centralised and professionally oriented approach (Lilleker \& Negrine, 2003; Reeves, 2007; Wring 1997). Furthermore political science literature has shown that Conservative election strategy over recent elections has become more centralised (Denver et al, 2003; Fisher \& Denver, 2008). It should however be stressed that the degree of central co-ordination was not common and consistent across all local parties which were represented in the study, and there was a high degree of diversity between constituencies. As a respondent remarked: 'I think it goes back to where you are in the party's hierarchy of attention' (Respondent 9).Generally, however one can discern that the local parties with the lowest levels of electoral swing and therefore more vital for the Conservative Party gaining an overall majority, tended to be more co-ordinated from the centre, and those with weaker electoral prospects were conversely less co-ordinated and supported.

Whilst it is possible to discern that some respondents did not view the co-ordination positively and in a way which supports them, this again cannot represent an unequivocal stance. This is because some respondents seemed to see growing co-ordination (at least in part) as a form of support. What however is perhaps clear is that there is a 'fine line' between higher levels of the party providing appropriate support on local political marketing to local parties, or alternatively being perceived as trying to gain undue and unnecessary influence over conduct of a local political marketing strategy.

\section{Discussion and Implications}

In this section, the paper discusses the implication of the research. Initially this is done in terms of the implications for some key themes in marketing theory. However later in the 
section, a broader perspective is taken in terms of the possible implications of this study for the public sector.

\section{Management of visual identity}

The provision by the Conservative Party of visual brand identity guidance to lower levels of the party, has linkages to literature which argues for the need of visual brand identity documentation to enable visual brand consistency (Jordá-Albiňana et al, 2009; Simões et al, 2005; van den Bosch et al, 2006). Hence this finding has clear connections with the literature which views visual identity as being part of the corporate identity of the organisation (e.g. Abratt, 1989; Balmer, 2008; Bartholmé \& Melewar, 2009; Dowling, 1994). It also points towards the desire (albeit it in imperfect form for the Conservative Party) for organisations to move towards a more standardised approach to visual identity management (Melewar \& Saunders, 1999; 2000).

The update of the logo whilst presenting a 'modern-up-to date visual appearance of the organisation' (Bartholmé \& Melewar, 2009: 158) perhaps however fails to meet other key functions of visual identity, as evidenced in the literature, such as giving clarity over vision and values of the organisation (Balmer, 1998; Bartholmé \& Melewar, 2009). Moreover whilst the new logo aims to 'add value by stakeholders seeing and remembering the logo' (Hynes, 2009: 545), it remains an area of debate as to whether the logo can effectively 'serve as a signature of the ... [organisation] by clearly linking the shape, design or colour to the organisation it represents' (Hynes, 2009: 545). Despite these concerns the logo must now continue to build recognition ,familiarity and visibility (van Riel \& van den Ban, 2001; van den Bosch, 2006). 


\section{Consistency}

Delgado - Ballester (2012) has recently found that for brands that are familiar to audiences, moderate levels of message consistency improve awareness and create more positive and favourable attitudes towards the brand. This finding is encouraging for the Conservative Party, as it was noticeable from the study's findings that the party is trying to strive for consistency of language and messages. This emphasis also echoes the integrated marketing communications literature which argues the case for themes such as: 'consistency' (Fill, 2000; Moriarty, 1994; Navarro et, al, 2009), 'orchestration' (Duncan, \& Everett, 1994) 'clarity' (Fill, 2009), 'simplicity' (Fill, 2009) and 'synergy' (Moriarty, 1994) in messages transmitted via internal and external communication tools. However there needs to be a recognition that language and message consistency is particularly challenging for non-profit organisations in general, given the human and financial resource constraints they face. This is because non-profit organisations are heavily reliant on volunteers to communicate messages to external audiences (Henley, 2001). This is certainly the case for the Conservative Party, and political parties more generally.

\section{Communicating the brand values}

The findings of the study in relation to values clearly have linkages with the brand management literature. A key theme of this literature is that the brand values of the organisation (i.e. the brand identity) need to be as far as possible aligned with the external perceptions of the brand (i.e. brand image) (de Chernatony et al, 2004; 2006, Urde, 2003). The study contributes to theory as it provides an example of how organisations struggle to collectively agree on their brand values (de Chernatony et al, 2004; Urde, 2003). This may lead to a sense of ambiguity when internal brand identity (as expressed through organisational members' external communication of brand values) may not be consistently 
interpreted by the organisation's external publics. This is problematic, as the need for consistency has been said to be important in building a coherent brand identity/ image (Brøn, Engell \& Matinsen, 2006; de Chernatony et al, 2006); a theme which is also echoed in Wallace et al (2011). A partial explanation underpinning this may be that the values of the brand are not as effectively aligned to some local organisational members' values as they could be, and thus there is not complete 'buy in' to the new modern brand (Thomson et al, 1999). In fact there may be some instances in the party where organisational members 'may be reluctant, or even sceptical, about the defined core values' (Thorbjørnsen \& Supphellen, 2011: 69). As Vallaster and de Chernatony (2005: 182) assert: 'brand's values need to be anchored in their minds and hearts to encourage brand supporting behaviour'. An alternative explanation may be that the party has not effectively communicated what its brand values are. This is consistent with the argument of King and Grace (2005) that an organisation's member's ability to communicate the brand consistently is influenced by their awareness and understanding of the brand strategy.

\section{Communicating a modern brand image}

It was noticeable from the study that the Conservative Party were trying to present a newer fresher image that distanced itself from its sometimes past perceived image, that the party was too far to the right of mainstream electoral opinion. The findings of the study theoretically align with the literature on brand image (e.g. Aaker, 1991; Dichter, 1985; Keller, 1993; Park et al, 1986) and in particular an organisation's leader's role in personifying, symbolising and communicating that brand image (Smith, 2001). Such an extension of the brand image concept to politics is justified by Cian's (2011: 165) assertion that: 'theoretically speaking, 'brand image' is a broad concept, which can be applied to organizations, corporates, products or services. Lately, it can also be applied to political parties'. There are however numerous interpretations of what a constitutes brand image, but a 
common thread throughout many of the definitions is that the consumer stores a series/ network of mental associations in their mind about a particular brand; and thus it is this that can be said to constitute a brand image (Aaker, 1991; Dichter, 1985; Keller, 1993). Hence in the case of a political party, a voter forms a brand image of a politician and / or political candidate by building a cognitive structure of brand associations, as collected, processed and stored via a voter's exposure to political messages. This image may be recalled at the decision making point to judge the extent or otherwise of congruity between the brand on offer and their own self concept (Dolich, 1969; Hogg et al, 2000; Jamal \& Al-Marri, 2007, Sirgy et al, 1997). The leader of the party provides assistance in this respect by providing a brand personality (Guzmán \& Sierra, 2009; Smith \& French, 2011). Thus in Aaker's (1997) frame of reference; s/he is communicating and personifying a series of human characteristics associated with the brand. The brand personality of the leader can therefore be used as a cognitive anchor for brand image associations.

\section{Data Management and Market Orientation}

There is evidence that the Conservative Party are increasingly making use of database driven marketing to target geodemographic and lifestyle voters segments. In particular, it can be seen how internal data is being increasingly combined, (and sometimes replaced with) external commercial data sources (Vasanen \& Raulas, 2006). There is also evidence of data mining taking place through what could essentially be termed a decision support system (Jackson, 2005b). The aim of data mining seems to be to identity segments that can be targeted with customised marketing messages via direct marketing techniques (D’Auria Stanton, 2006; Drew et al, 2001; Murray \& Scime, 2010; Peltier \& Schribrowsky, 1997; Samli et al, 2002; Vasanen \& Raulas, 2006). 
The evidence seems to point towards a tendency of greater centralisation in the party. Despite this it can be asserted that centralisation in the Conservative Party is typically lower in magnitude than many corporate organisations. However if we apply market orientation theory, centralisation of the Conservative Party may mitigate against the effectiveness of political marketing. Research has shown the greater the degree of centralization, the lower the degree of market orientation (Jaworski \& Kohli, 1993). This is important as market orientation can be defined as the 'organizationwide generation of marketing intelligence pertaining to current and future needs, dissemination of the intelligence across departments, and organizationwide responsiveness to it' (Kohli \& Jaworski, 1990: 6). Clearly it can be seen that 'generation of marketing intelligence' is increasingly reliant on third party data sources, rather than systematic market intelligence data collection by local constituency parties. The 'dissemination of the intelligence' within the Party also has limitations since internal web site systems were not as effective as they could have been. Moreover there were claimed to be a lack of other briefing notes and documents on political marketing. Given the limitations of dissemination, it also follows the 'responsiveness to market intelligence' is not as effective as it may have been. Moreover, it is of concern that in some cases there is an under-current of competition both between local parties and higher levels, as well as between candidates and local parties. This is of concern as according to market orientation literature, team working (Harris, 1996), interfunctional coordination (Lafferty \& Hult, 2001), and good internal communication (Harris, 2000), rather than conflict (Jaworski \& Kohli, 1993) enhance the market orientation of the organisation.

\section{Implications for the Public Sector}

This study also has implications for the public sector. This is because locally elected politicians and public sector officials are to some extent inter-dependent with each other (Butler \& Collins, 2001). As Singh and Fredericks (2005: 243-244) assert: 
'one tenet of marketing is that both government and public are open systems and in order to co-exist, mutually beneficial exchanges must exist through which mutually beneficial outcomes are derived. As an open system, each contributes to the maintenance, survival and growth of the other'.

Hence it therefore follows that there is a need for a closer relationship between public sector marketing and political marketing literatures (Butler \& Collins, 2001;2007). This view is supported by O'Cass (2003: 69) who argues that 'political marketing's multiple audiences and lack of profit orientation give it more commonality with marketing for public and nonprofit organizations, than the commercial marketing of goods and services'. This interdependency between public sector marketing and political marketing is in part a biproduct of the New Public Management discourse (Butler et al, 2007; Hutton et al, 2011) which promulgates the language of choice, 'citizen consumers', competition, marketisation etc; language which of course lends itself to a marketing domain, and as such provides an analytical bridge between the public sector marketing and political marketing literatures.

At a more pragmatic level, 'the kinds of services commonly associated with political influence and constituency activity indicate a convergence of politics and public service provision' (Butler \& Collins, 2001:1026). This is because:

'marketing for most politicians involves being associated with actual public service delivery... Elected politicians continuously engage with their constituents. Their permanent campaigns do not simply consist of ongoing communication and a local presence, but invariably involve delivering public services to their constituents' (Butler et al, 2007: 91-102).

Hence politicians are influencing and being influenced by local public service delivery and performance (Butler \& Collins, 2001; 2007). This co-dependency between the political and public sector is required, given most public services are funded by taxpayers and therefore 'there is a greater degree of accountability as to how resources are used' (Lloyd,2005: 38; Lees-Marshment, 2005b). 
The public sector needs to appreciate the processes of political marketing, and how political marketing activities are facilitated; especially during election periods. As a starting point, it needs to recognise that the language of local political marketing is frequently conflated with that of campaigning by local political party actors. It easy to see how the public sector is likely to become embroiled in political party battles. Hence local political marketing activities may lead to some combination of praise, attack and counter-attack on local public sector services across varied political party communication devices. The public sector needs to mitigate against this (where possible and subject to resource constraints) by engaging in its own public sector marketing campaigns, that communicates its politically neutral information.

One feature which comes out of this study is how local political marketing is becoming increasingly reliant on data. Given that the public sector is likely to have the greatest volume of locally relevant data, it is likely that this data (subject to data protection legislative provisions) is sought for political purposes. In these circumstances, the public sector is likely to become involved in claim and counter-claim between the political parties about the interpretation of the data throughout the multitude of communication devices used by political parties. Moreover, where local political parties engage in their own activist led local data collection, they are likely to have information on the electoral perceptions of public services. Clearly this presents a challenge for the local public sector, as they were not engaged in the methodology and research design underpinning this data. Yet the public sector can be influenced by the results of such studies which in some circumstances may have methodological weaknesses, be poorly analysed, or may be inherently politicised. This is a particular issue given the tendency of local political marketing to simplify political messages for effective electoral processing, perception, storage and recall. In these circumstances, the 
language and message used to communicate by local political parties may in actual fact oversimplify the nature of public sector services, and lead to public misunderstanding.

The level of pressure experienced by the public sector as a result of local political marketing is contingent on a number of factors. First, is the period in the electoral cycle; with the period leading up to elections being the most intense. Second, the local political context will influence the magnitude of local pressure endured by the local public sector. This is because where a locality is dominated by one political party, and hence the election result is very predictable, then the extent of competition between political parties is likely to be far less intense. Where political party competition is more intense because election results are less predictable, then the public sector is likely to be more affected by local political marketing campaigns. The pressure can be most intense where a particular constituency is a marginal seat, and hence there is a greater degree of national party interest in the local political marketing strategy. In these circumstances the intensity, professionalism and resourcing of a local political marketing strategy may expose local public service provision to national debate. Finally, the public sector also needs to be aware that whilst periods of political marketing activity are most intense around election periods, local political parties are engaged increasingly in a 'permanent' campaign. This means that public services can at any point in time be affected by local political marketing activities.

\section{Conclusion}

In summary, the study has found there to be acknowledgement of local political marketing in the Conservative Party by a majority of respondents, although this is not unequivocal as some respondents exhibited some reservations about the prevalence and extent of local political marketing approaches in their local parties. This is partially because of the conflation of 
political marketing with campaigning as well as candidates perceiving themselves to be primarily responsible for political marketing rather than sharing the responsibility with local parties. Furthermore it was argued that the models of business marketing cannot be superimposed onto the political party.

The research found that local political marketing in the Conservative Party was associated with principal components which included: (i) visual identity; (ii) language and messages; (iii) values; (iv) image; (v) communication devices; (vi) awareness raising; (vii) data management and targeting, and (viii) simplification.

The levels of support from higher levels of the party in respect of local political marketing were found to be highly varied across different constituencies. Where support was acknowledged it was typically viewed as being in the form/ language of campaigning, and tended to be provided by a network of regional party professionals. The most prevalent form of support was in terms of visual identity materials. The ICT support available to local parties did seem to have some weaknesses in terms of its usability. It was also noted that there was evidence of a growing coordination and influence of higher levels of the party in local political marketing activities in constituencies. However this tended to be the case where a seat was deemed to be more 'winnable', and was ultimately important in terms of the attempt (albeit unsuccessful) to gain a parliamentary majority. The study has shown how these findings are related to themes in marketing theory including management of visual identity, communicating brand values, communicating a modern brand image, data management and market orientation, as well as more broader implications for the public sector.

\section{Managerial Implications}

This section aims to communicate a series of implications and recommendations on how local political marketing could be developed further by the Conservative Party. In addition 
these implications are developed further in order to suggest ways that the lessons learnt from this study may have some use for other political marketing practitioners in other political parties, as well as for political marketing academics.

The study found that there is considerable commercial and marketing expertise available to the Conservative Party at grass roots level. This expertise should be more effectively utilised in the party for political marketing purposes, whilst at the same time recognising that what members have learnt in the world of business may not be directly transferable to the political arena. Hence further training specifically in political marketing could be offered to these individuals and for candidates, so that they can be valuable in cascading political marketing expertise throughout the party. These findings are likely to have wider currency in other political parties, as amongst a large political party there is likely to be members with such commercial and marketing expertise. Such individuals are of significant potential value to a resource constrained political party as they are a means through which marketing could be spread throughout a political party. However marketing expertise is not available to all constituency parties, hence this study would recommend a process of 'twinning' weaker local parties with stronger local parties in order to boost political marketing across the entire organisation.

The Conservative Party should consider linking more clearly the democratic regional voluntary structures of the party, with the regional professionals so as to sustain local political marketing effectiveness. This would therefore assist in enabling local parties to understand that local political marketing should be a permanent relationship building process with voters. This recommendation is also of value to other political parties as there is a tendency that with a greater professionalization of political parties, the members may perceive themselves as reducing in importance relative to the party professionals. Hence, in order to counter any such anxiety, political parties should ensure that there are appropriate 
linkages between the democratic and party professionals' structures. Returning to the Conservative Party, this recommendation may have particular value as the research could sense that there are the beginnings of some discontent amongst active party members as to the growing co-ordination of political marketing activities.

There is evidence that the Conservatives are making growing and effective use of commercially available data for the purposes of segmentation and targeting in local constituencies. The system Merlin should be 'rolled out' further to more local parties. However, this study could sense that the Merlin system was not being fully used to its maximum capacity. Too many local parties seemed to be relying on the commercial data and not collecting primary data from the local constituency which could be inputted into the system. The use of targeting could have been arguably more effective if local parties had more systematic ways of collecting data locally. This local data collection process could be, if managed properly, a genuine source of involvement for party members who would then be able to have a sense of pride that they are contributing to Conservative progress by helping to collect and record data. If there is too much reliance on commercial data, then the membership will struggle to perceive their relevance, and this may result in falling membership rolls in local parties. Indeed the importance of local members in Conservative Party local campaigning is stressed in the political science literature (e.g. Seyd \& Whiteley, 2004; Whiteley et al, 1994). Hence, to quote Whiteley et al (1994: 218): 'a party that which allows its grass roots to wither and decline is likely to run into serious electoral problems'(Whiteley et al, 1994: 218).

For other political parties, there is also a danger that a greater professionalization of political parties leads them to neglect the importance of political party members in conducting market research in local constituencies. Political marketing practitioners should recognise that local members represent a valuable resource in local data collection that can be used to inform 
effective segmentation and targeting of political messages. In other words, members' data collection cannot be replaced by commercial secondary data, as locally collected data is a significant way to gain rich and detailed information on voters' political concerns. Commercial data may be unable to provide such fully comprehensive and detailed information at a very local level.

Finally, the study would recommend that the information systems in the Conservative Party are revisited as the study found that some people in the party were confused by the differing systems and how they could be effectively utilised. Hence, this author would suggest that there is a need before the next general election to have one unified information system that is easy to use by people in the party. Clearly other political parties should also ensure that there are appropriate information systems that can be accessed and utilised to meet the needs of local parties. Thus political marketing professionals at the centre of the party have a significant role in implementing such support systems.

\section{Limitations and Future Directions for Research}

The study has a number of limitations. The first most obvious limitation is that the study conducted 12 interviews, thus comprising one interview in each selected constituency. Therefore, this exploratory study cannot account for all the possible views and opinions in relation to local political marketing in the Conservative Party. Second, whilst lessons may be learnt which may be replicated into understanding local political marketing in other political parties, future research would be required in order to test the outcomes of this research in other contexts. Thirdly, the research presents a particular 'snapshot' in time, whilst the practices of local political marketing are evolving. Hence, research will be required in the future to update our understanding of local political marketing in the Conservative Party. This is likely to be especially the case in the future given the coalition with the Liberal Democrats 
is likely to have significant implications for local political marketing at the next general election.

\section{References}

Aaker, D. (1991). Managing Brand Equity, New York: The Free Press.

Aaker, J. (1997). Dimensions of brand personality. Journal of Marketing Research, 36, 346356.

Abratt, R. (1989). A new approach to corporate image management process. European Journal of Marketing, 34 (3), 63-76.

Baines, P., \& Egan, J. (2001). Marketing and political campaigning: mutually exclusive or exclusively mutual?. Qualitative Market Research: An International Journal, 4(1), 25-34. Baines, P., Harris, P., \& Lewis, B. (2002).The political marketing planning process: improving image and message in strategic target areas. Marketing Intelligence and Planning, $20(1), 6-14$.

Baines, P., Worcester, R., Jarrett, D., \& Mortimore, R. (2003). Market segmentation and product differentiation in political campaigns: a technical feature perspective. Journal of Marketing Management, 19, (1/2), 225-249.

Baines, P., Worcester, R., Jarrett, D., \& Mortimore, R. (2005). Product attribute based voter segmentation and resource advantage theory. Journal of Marketing Management, 21 (9/10), $1079-1115$

Balmer, J. (1998). Corporate identity and the advent of corporate marketing. Journal of Marketing Management, 14 (8), 963-996.

Balmer, J. (2008). Identity based views of the corporation: Insights from corporate identity, organisational identity, social identity, visual identity, corporate brand identity and corporate image. European Journal of Marketing, 42 (9-10), 879-906. 
Bartholmé , R., \& Melewar, T. (2009). Adding new dimensions to corporate identity management and corporate communication: exploring the sensory perspective. The Marketing Review, 9 (2), 155-169.

BBC. (2010). Q\&A: Tory-Lib Dem Coalition. Retrieved 24 $4^{\text {th }}$ September 2010 from: http://www.bbc.co.uk/news

Bourgeois, L. (1979). Toward a method of middle-range theorizing. Academy of Management Review, 4 (3), 443-447.

Bowen, G. (2009). Supporting a grounded theory with an audit trail: an illustration. International Journal of Social Research Methodology, 12(4), 305-316.

Bowler, S. \& Farrell, D. (1992a). Electoral Strategies and Political Marketing. Basingstoke: MacMillan.

Bowler, S., \& Farrell, D. (1992b). The study of election campaigning. In S. Bowler, \& Farrell, D. (Eds.), Electoral Strategies and Political Marketing (pp.1-23). Basingstoke: MacMillan.

Brøn, P., Engell, A., \& Matinsen, H. (2006). A reflective approach to uncovering actual identity. European Journal of Marketing, 40 (7/8), 886-901.

Butler, P., \& Collins, N. (1994). Political marketing: structure and process. European Journal of Marketing, 28 (1), 19-34.

Butler, P., \& Collins, N. (2001). Payment on delivery: recognising constituency service as political marketing. European Journal of Marketing, 35 (9/10), 1026-1037.

Butler, P., Collins, N. \& Fellenz, M. (2007). Theory-Building in Political Marketing. Journal of Political Marketing, 6 (2-3), 91-107.

Cian, L. (2011). How to measure brand image: A reasoned review. The Marketing Review, 11 (2), 165-187. 
Cosgrove, K. (2007). Branded Conservatives: How the brand brought the right from the fringes to the center of American Politics, New York: Peter Lang.

Creswell, J. (2007). Qualitative Inquiry and Research Design: Choosing Among Five Approaches. $2^{\text {nd }}$ Edition. Thousand Oaks: Sage.

Creswell. J., \& Miller, D. (2000). Determining validity in qualitative inquiry. Theory into Practice, 39 (3),124-130.

D’ Auria Stanton, A. (2006). Bridging the academic/practitioner divide in marketing: An undergraduate course in data mining. Marketing Intelligence and Planning, 24 (3), 233-244. de Chernatony, L., Drury, S., \& Segal-Horn, S. (2004). Identifying and sustaining services brands' values. Journal of Marketing Communications, 10 (2), 73-93.

de Chernatony, L., Cottam, S., \& Segal-Horn, S. (2006). Communicating services brands' values internally and externally. The Service Industries Journal, 26 (8), 819-836.

Delgado-Ballester, E., Navarro, A. \& Sicilia, M. (2012). Revitalising brands through communication messages. European Journal of Marketing, 46 (1), 31-51.

Denver, D., Hands, G., Fisher, J., \& MacAllister, I. (2003). Constituency campaigning in Britain: centralisation and modernization. Party Politics, 9(5), 541-559.

Denver, D., Hands, G., Fisher, J., \& MacAllister, I. (2004). The electoral impact of constituency campaigning in Britain, 1992-2001. Political Studies, 52 (2), 289-306. Denzin, N. (1970; 1978). The Research Act: A Theoretical Orientation to Sociological Methods. New York: McGraw Hill.

Dermody, J., \& Hanmer-Lloyd, S. (2005). Promoting distrust? A chronicle of the 2005 British general election advertising campaigns. Journal of Marketing Management, 21(9/10), 1021-1047. 
Dermody, J., \& Scullion, R. (2001). An exploration of the advertising ambitions and strategies of the 2001 general election. Journal of Marketing Management, 17 (9/10), 969987.

Dichter, E. (1985). What's in an image?. Journal of Consumer Marketing, 2 (1), 75-81.

Dolich, I. (1969). Congruence relationships between self images and product brands, Journal of Marketing Research, 15, 80-84.

Dowling, G. (1994). Corporate Reputation-Strategies for Developing the Corporate Brand, London: Kogan Page.

Drew, J., Mani, D., Betz, A. \& Datta, P. (2001). Targeting customers with statistical and datamining techniques. Journal of Service Research, 3 (3), 205-219.

Duncan, T., \& Everett, S. (1993). Client Perceptions of Integrated Marketing Communications. Journal of Advertising Research, 3 (3), 30-39.

Egan, J. (1999). Political marketing: lessons from the mainstream. Journal of Marketing Management, 15 (6), 495-503.

Farrell, D. \& Wortmann, M.. (1987). Party strategies in the electoral market: political marketing in West Germany, Britain and Ireland. European Journal of Political Research, 15 (3), 297-318.

Fill, C. (2000). Essentially a matter of consistency, Marketing Review, 1 (4),409-425.

Fill, C. (2009). Marketing Communications: Interactivity, Communities and Content, $5^{\text {th }}$ Edition, London: Prentice Hall.

Fisher, J., \& Denver, D. (2008). From foot-slogging to call centres and direct mail: a framework for analysing the development of district-level campaigning. European Journal of Political Research, 47 (6), 794-826. 
Fisher, J., \& Denver, D. (2009). Evaluating the electoral effects of traditional and modern modes of constituency campaigning in Britain 1992-2005. Parliamentary Affairs, 62 (2), 196-210.

Gabriel, C. (1990) . The validity of qualitative market research. Journal of the Market Research Society. 32 (4), 507-519.

Glaser, B. \& A. Strauss. (1967; 1999). The Discovery of Grounded Theory: Strategies for Qualitative Research, New York: Aldine and Gruyter.

Guzmán, F. \& Sierra, V. (2009). A political candidate's brand image scale: Are political candidates brands?. Journal of Brand Management, 17 (3), 207-217.

Harris, L. (1996). Cultural obstacles to market orientation. Journal of Marketing Practice: Applied Marketing Science, 2 (4), 36-52.

Harris, L. (2000.) The organizational barriers to developing market orientation, European Journal of Marketing, 34,(5/6), 598-624.

Harris, P., Fury, D., \& Lock, A. (2006). Do political parties and press influence the public agenda: a content analysis of press coverage in the 2001 UK general election. Journal of Political Marketing, 5 (3), 1-28.

Harrop, M. (1990). Political marketing, Parliamentary Affairs, 43(3), 277-291.

Henley, T. (2001). Integrated marketing communications for local nonprofit organisations: Developing an integrated marketing communications strategy. Journal of Nonprofit and Public Sector Marketing, 9 (1-2), 141-155.

Henneberg, S. (2002). Understanding political marketing. In, O’Shaughnessy, N. \& Henneberg, S. (Eds.) The Idea of Political Marketing, (pp. 93-170) London: Praeger. Henneberg, S., \& Eghbalian, S. (2002). Kirchheimer's catch-all party: a reinterpretation in marketing terms. In, O’ Shaughnessy, N. \& Henneberg, S. (Eds.) The Idea of Political Marketing, (pp. 67-92). London: Praeger. 
Hogg, M., Cox, A. \& Keeling, K. (2000). The impact of self-monitoring on image congruence and product/ brand evaluation. European Journal of Marketing, 34 (5-6), 641666.

Hughes, A., \& Dann, S. (2010). Australian political marketing: substance backed by style, In Lees-Marshment, J. Strömbäck, J. \& Rudd, C. (Eds.) Global political marketing,(pp.82-96) Oxford: Routledge, Hutcheson, D. (2006). How to win elections and influence people: The development of political consulting in post-communist Russia. Journal of Political Marketing, 5 (4), 47-70. Hutton, J,. Leung V., Mak, A., Varey, R., \& Watjatrakul, B (2011). Students, patients, citizens, and believers as "customers": A cross national exploratory study. Journal of Nonprofit \& Public Sector Marketing, 23 (1) 41-70.

Hynes, N. (2009). Colour and meaning in corporate logos: an empirical study. Journal of Brand Management, 16 (8), 545-555.

Jackson, N. (2005a). Political parties, the internet and the 2005 general election: third time lucky?. Internet Research, 17 (2) 249-271.

Jackson, T. (2005b). CRM: From 'art to science'. Database Marketing \& Customer Strategy Management, 13 (1), 76-92.

Jamal, A. \& Al-Marri, M. (2007). Exploring the effect of self-image congruence and brand image preference on satisfaction: the role of expertise. Journal of Marketing Management, 23 (7/8), 613-629.

Jaworski, B., \& Kohli, A. (1993). Market Orientation: Antecedents and Consequences. Journal of Marketing, 57, 53-70.

Johnson, D. (2012). Formative years of political consulting in America, 1934-2000. Journal of Political Marketing, 11 (1-2), 54-74. 
Jordá-Albiňana , B., Ampuero-Canellas, O., Vila, N. \& Rojas-Sola, J. (2009). Brand identity documentation: a cross-national examination of identity standards manuals. International Marketing Review, 26 (2), 172-197.

Kaid, L. (2012). Political advertising as political marketing: A retro-forward perspective. Journal of Political Marketing, 11 (1-2), 29-53.

Keller, K. (1993). Conceptualising, measuring and managing consumer-based brand equity. Journal of Marketing, 57 (1) 1-22.

King, C., \& Grace, D.(2005). Exploring the role of employees in the delivery of the brand: A case study approach. Qualitative Market Research: An International Journal, 8 (3), 277-295. Kirchheimer, O. (1966). The transformation of Western European party systems. In J. La Polombara (Eds.), Political Parties and Political Development. (pp. 177-200), Baltimore: Princeton University Press.

Kohli, A., \& Jaworski, B. (1990). Market orientation: The construct, research propositions, and managerial implications. Journal of Marketing, 54 (2), 1-18.

Lafferty, B., \& Hult, G. (2001). A synthesis of contemporary market orientation perspectives. European Journal of Marketing, 35 (1/2), 92-109. Lees-Marshment, J. (2001a). Political Marketing and British Political Parties: The Party's Just Begun, Manchester: Manchester University Press.

Lees-Marshment, J. (2001b). Marketing the British Conservatives 1997-2001. Journal of Marketing Management, 17 (9/10), 929-941.

Lees-Marshment, J. (2004a). The Political Marketing Revolution, Manchester: Manchester University Press.

Lees-Marshment, J. (2004b). Mis-marketing the Conservatives: The limitations of style over substance. The Political Quarterly, 75 (4), 392-397. 
Lees-Marshment, J. (2005a). The marketing campaign: The British election of 2005. Journal of Marketing Management. 21(9/10), 1151-1160.

Lees-Marshment, J. (2005b). Introduction, Journal of Non-profit \& Public Sector Marketing, 14 (1-2), 1-3.

Lees-Marshment, J. (2009). Political marketing and the 2008 New Zealand election: A comparative perspective. Australian Journal of Political Science, 44 (3), 457-475.

Lees-Marshment, J., \& Quayle, S. (2001). Empowering the members or marketing the party? The Conservative reforms of 1998. The Political Quarterly, 72 (2), 204-212.

Lilleker, D. (2005a). Local campaign management: winning votes or wasting resources. Journal of Marketing Management. 21(9/10), 979-1003.

Lilleker, D. (2005b). The impact of political marketing on internal party democracy. Parliamentary Affairs, 58 (3), 570-584.

Lilleker, D. (2006). Local political marketing: political marketing as public service, In Lilleker, D., Jackson, N., Scullion, R. (Eds,) The Marketing of Political Parties, (pp. 206230), Manchester: Manchester University Press.

Lilleker, D., \& Lees-Marshment, J. (2005) (Eds.). Political Marketing: A Comparative Perspective, Manchester: Manchester University Press.

Lilleker, D., \& Negrine, R. (2003). Not big brand names but corner shops: marketing politics to a disengaged electorate. Journal of Political Marketing, 2(1) 55-76.

Lincoln, Y., \& Guba. E. (1985). Naturalistic Inquiry. London: Sage.

Lloyd, J. (2005). Square peg, round hole? Can marketing-based concepts such as the 'product' and the 'marketing mix' have a useful role in the political arena. Journal of Nonprofit \& Public Sector Marketing, 14 (1-2), 27-46.

Lock. A, \& Harris, P. (1996). Political marketing: vive la difference. European Journal of Marketing, 30 (10/11), 14-24. 
Maarek, P. (1995). Political Marketing and Communication, London: John Libbey.

Melewar. T., \& Saunders. J. (2000). Global corporate visual identity systems: using an extended marketing mix. European Journal of Marketing, 34 (5/6), 538-550.

Melewar. T., \& Saunders. J. (1999). International corporate visual identity: standardisation or localization?. Journal of International Business Studies, 30 (3), 583-598.

Merton, R. (1968). Social Theory and Social Structure. New York: Free Press.

Miles, M. \& Huberman, A. (1984). Qualitative Data Analysis: A Sourcebook of New

Methods. London: Sage.

Moriarty, S. (1994). PR and IMC: The benefits of integration. Public Relations Quarterly, 39 (3), 38-44.

Morse, J., Barrett, M., Mayan, M., Olson, K. \& J. Spiers. (2002). Verification strategies for establishing reliability and validity in qualitative research. International Journal of Qualitative Methods, 1 (2), 13- 22.

Murray, G., \& Scime, A. (2010). Microtargeting and electorate segmentation: Data mining the American national election studies. Journal of Political Marketing, 9 (3), 143-166.

Navarro, A., Sicilia, M., \& Delgado- Ballester, E. (2009). Integrated marketing communications: Effects of advertising- sponsorship strategic consistency. Euromed Journal of Business, 4 (3), 223-236.

Needham, C. (2005). Brand leaders, Clinton, Blair and the limitations of the permanent Campaign. Political Studies, 53 (2), 343-361.

Needham, C. (2006). Brands and political loyalty. Journal of Brand Management, 13(3), 178-187.

Newman, B. (1999). The Mass Marketing of Politics: Democracy in an Age of Manufactured Images, London: Sage. 
Newman, B. \& Sheth, J. (1985). A model of primary voter behavior. Journal of Consumer Research, 12, 178-187.

Newman, B. \& Sheth, J. (1987). A Theory of Political Choice Behaviour. London: Praeger Press.

Niffenegger, P. (1989). Strategies for success from the political marketers. Journal of Consumer Marketing, 6 (1), 45-51.

Nimmo, D. (1975). Images and voters' decision making processes. Advances in Consumer Research, 2 (1), 771-781.

O’Cass, A. (2003) An exploratory assessment of the political product: Proclamations of the faithful. Journal of Non-profit \& Public Sector Marketing, 11(2), 67-98.

Ormrod, R., Henneberg, S., Forward, N., Miller, J., \& Tymms, L. (2007).Political marketing in untraditional campaigns: the case of David Cameron's Conservative Party leadership victory. Journal of Public Affairs, 7 (3), 235-248.

O’Shaughnessy, N. (1990). The Phenomenon of Political Marketing. London: MacMillan. O’Shaughnessy, N. (2001). The marketing of political marketing. European Journal of Marketing, 35 (9/10), 1047-1057.

O’Shaughnessy, N. \& Henneberg, S. (2002). (Eds.) The Idea of Political Marketing, London: Praeger.

Panagopoulos, C., \& Francia, P. (2009). Grassroots mobilization in the 2008 Presidential Election. Journal of Political Marketing, 8 (4), 315-333.

Panagopoulos, C., \& Green, D. (2008). Field experiments testing the impact of radio advertisements on electoral competition. American Journal of Political Science, 52 (1), 156168.

Panebianco, A. (1988). Political Parties: Organisation and Power. Cambridge: Cambridge University Press. 
Park, C., Jaworski, B., \& MacInnis, D. (1986). Strategic brand concept-image management, Journal of Marketing, 50 (4), 136-145.

Peltier, J., \& Schribrowsky J. (1997). The use of need-based segmentation for developing segment specific direct marketing strategies. Journal of Direct Marketing, 11 (4), 53-62.

Phillips, J., Reynolds, T., \& Reynolds, K. (2010). Decision-based voter segmentation: an application for campaign message development. European Journal of Marketing, 44 (3), $310-330$.

Reeves, P. (2007). Anatomy of an Internal Branding Programme: The Case of the Liberal Democrats. Unpublished PhD Thesis: University of Birmingham.

Reeves, P., de Chernatony, L. \& Carrigan, M. (2006). Building a political brand: ideology or voter-driven strategy. Journal of Brand Management, 13 (6), 418-428.

Reid, D. (1988). Marketing the political product. European Journal of Marketing, 22 (9), $34-47$.

Riege, A. (2003). Validity and reliability tests in case study research: a literature review with "hands on" applications for each research phase. Qualitative Market Research: An International Journal, 6 (2), 75-86.

Samli, A. Pohlen, T. \& Bozovic, N. (2002). A review of data mining techniques as they apply to marketing: Generating strategic information to develop market segments. The Marketing Review 3 (2), 211-227.

Savigny, H. (2005). Labour, political marketing and the 2005 election: a campaign of two halves. Journal of Marketing Management, 21 (9/10), 925-941.

Scammell, M. (1994). The phenomenon of political marketing: the Thatcher contribution. Contemporary British History, 8 (1), 23-43.

Scammell, M. (1995). Designer Politics: How Elections Are Won. Basingstoke: MacMillan. 
Scammell, M. (1996). The odd couple: marketing and Maggie. European Journal of Marketing, 30 (10/11), 114-126.

Schneider, H. (2004). Branding in politics: manifestations, relevance and identity-orientated management. Journal of Political Marketing, 3(3), 41-67.

Seawright, D. (2005). On a low road': The 2005 Conservative campaign. Journal of Marketing Management, 21 (9/10),943-957.

Seyd, P., \& Whiteley, P. (2004). British party members: An overview. Party Politics, 10 (4), $355-366$.

Shama, A. (1975). Applications of marketing concepts to candidate marketing. Advances in Consumer Research, 2 (1), 793-801.

Simões, C., Didd, S., \& Fisk, R. (2005). Managing corporate identity: an internal perspective, Journal of the Academy of Marketing Science, 33 (2), 153-168.

Singh, T., \& Fredericks, E. (2005). An exploratory assessment of voter and governmental interface on pertinent issues facing American children and youth. Journal of Non-profit \& Public Sector Marketing, 14 (1-2), 223-245.

Sirgy, M., Grewal, D. Mangleburg, T., Park, J., Chon, K. Claiborne, C., Johar, J. \& Berman, H. (1997). Assessing the predictive validity of two methods of measuring self-image congruence. Journal of the Academy of Marketing Science, 25 (3), 229-241.

Smith, G. (2001). The 2001 General Election: Factors influencing the brand image of political parties and their leaders. Journal of Marketing Management, 17 (9/10), 989-1006. Smith, G., \& French, A. (2011). Measuring the changes to leader brand associations during the 2010 election campaign. Journal of Marketing Management, 27 (7-8), 718-735. Smith, G., \& Hirst, A. (2001). Strategic political segmentation: A new approach for a new era of political marketing. European Journal of Marketing, 35 (9/10), 1058-1073. 
Smith, G., \& Saunders. J. (1990). The application of marketing to British politics. Journal of Marketing Management, 5 (3), 295-306.

Strauss, A. \& Corbin, J. (1990). Basics of Qualitative Research. London: Sage.

Thomson, K., de Chernatony, L., Arganbright, L. \& Khan, S. (1999). They buy-in benchmark: How staff understanding and commitment impact brand and business performance. Journal of Marketing Management, 15, 819-835.

Thorbjørnsen, H., \& Supphellen, M. (2011). Determinants of core value behaviour in service brands. Journal of Services Marketing, 25 (1), 68-76.

Towner, T., \& Dulio, D. (2012). New media and political marketing in the United States: 2012 and beyond. Journal of Political Marketing, 11 (1-2), 95-119.

Urde, M. (2003). Core value-based corporate brand building, European Journal of Marketing, 37 (7), 1017-1040.

Vallaster, C., \& de Chernatony, L. (2005), Internalisation of services brands: The role of leadership during the internal brand building process. Journal of Marketing Management, 21, 181-203.

van den Bosch. A., Elving, W., \& de Jong, M. (2006). The impact of organisational characteristics on corporate visual identity. European Journal of Marketing, 40 (7/8). 870885.

van Riel, C., \& van den Ban, A. (2001). The added value of corporate logos: an empirical study. European Journal of Marketing, 35 (3/4), 428-440.

Vasanen, J., \& Raulas, M. (2006). Building bridges for personalization: A process model for marketing. Journal of Interactive Marketing, 20 (1), 5-20.

Wallace, E., de Chernatony, L. \& I. Buil. (2011). How leadership and commitment influence bank employees' adoption of their bank's values. Journal of Business Ethics, 101 (3), 397414. 
Ward, I. (2003). Localizing the national: The rediscovery and reshaping of local campaigning in Australia. Party Politics, 9 (5), 583-600.

Whiteley, P. \& Seyd, P. (2003a). How to win a landslide by really trying: the effects of local campaigning on voting in the 1997 British general election. Electoral Studies, 22 (2), 301324.

Whiteley, P. \& Seyd, P. (2003b). Party election campaigning in Britain: The Labour Party, Party Politics, 9 (5), 637-652.

Whiteley, P., Seyd, P. \& Richardson, J. (1994). True Blues: The Politics of Conservative Party Membership. Oxford: Claredon Press.

Wring, D. (1996). Political marketing and party development in Britain: a "secret" history. European Journal of Marketing, 30 (10/11), 92-103.

Wring, D. (1997). Political Marketing and the Labour Party: The Relationship Between Campaign Strategy and Intra-organisational Power. Unpublished PhD Thesis, University of Cambridge.

Wring, D. (2002). Conceptualising political marketing, a framework for election campaign analysis., In O’ Shaughnessy, N. \& Henneberg, S. (Eds.) The Idea of Political Marketing. (pp. 171-185) London: Praeger.

Yorke, D., \& Meehan, S. (1986). ACORN in the political marketplace. European Journal of Marketing, 20 (8), 63-76.

Zvulun, J. (2012). The single transferable vote and voter turnout in the 2004 local elections. Journal of Political Marketing, 11 (3), 123-142. 